\title{
Neural protection by naturopathic compounds-an example of tetramethylpyrazine from retina to brain
}

\author{
Zhiqun Tan
}

Published online: 1 September 2009

(C) The Author(s) 2009. This article is published with open access at Springerlink.com

\section{Erratum to: j ocul biol dis inform}

$$
\text { DOI 10.1007/s12177-009-9024-8 }
$$

The following article was mistakenly run in volume 2 , issue 2 (June 2009) instead of in the present special issue, for which it was intended. The publisher regrets the error.

\begin{abstract}
Given the advantages of being stable in the ambient environment, being permeable to the blood-brain and/or blood-eye barriers and being convenient for administration, naturopathic compounds have growingly become promising therapeutic candidates for neural protection. Extracted from one of the most common Chinese herbal medicines, tetramethylpyrazine (TMP), also designated as ligustrazine, has been suggested to be neuroprotective in the central nervous system as well as the peripheral nerve network. Although the detailed molecular mechanisms of its efficacy for neural protection are understood limitedly, accumulating evidence suggests that antioxidative stress, antagonism for calcium, and suppression of pro-inflammatory factors contribute significantly to its neuroprotection. In animal studies, systemic administration of TMP (subcutaneous injection, $50 \mathrm{mg} / \mathrm{kg}$ ) significantly blocked neuronal degeneration in hippocampus as well as the other vulnerable regions in brains of Sprague-Dawley rats following kainate-induced prolonged seizures. Results from us and others also demonstrated potent neuroprotective efficacy of TMP for retinal cells and robust benefits for brain
\end{abstract}

The online version of the original article can be found at http://dx.doi. org/10.1007/s12177-009-9024-8.

Z. Tan $(\bowtie)$

Department of Neurology,

University of California Irvine School of Medicine,

ZOT 4275 ,

100 Irvine Hall,

Irvine, CA 92697, USA

e-mail: tanz@uci.edu in Alzheimer's disease or other brain injury. These results suggest a promising prospect for TMP to be used as a treatment of specific neurodegenerative diseases. Given the assessment of the distribution, metabolism, excretion, and toxicity information that is already available on most neuroprotective naturopathic compounds such as TMP, preclinical data to justify bringing such therapeutic compounds to clinical trials in humans is feasible.

Keywords Naturopathic compounds .

Tetramethylpyrazine $\cdot$ Retina $\cdot$ Brain $\cdot$ Neuronal degeneration

\section{Introduction}

Neuronal degeneration, i.e., neuronal cell death, underlies the pathology and malfunction of many different neurological diseases occurring in both animals and human beings. Progressive and selective neuronal cell death in the central nervous system (CNS) and/or the peripheral nerve network has been profoundly implicated in the pathogenesis of neurodegenerative disorders including Alzheimer's disease (AD), Parkinson's disease, Huntington's disease, Lou Gehrig's disease or amyotrophic lateral sclerosis, multiple sclerosis, epilepsy, stroke, traumatic injury, age-related macular degeneration, glaucoma, prion diseases, infections, and so on $[1,2]$. Evidence is rapidly accumulating to suggest that selective neuronal cell death through necrosis and/or apoptotic mechanisms contributes significantly to the functional anomalies of specific neurologic disorders [1]. Changes of genetic, epigenetic, metabolic, and environmental factors might directly or indirectly cause (1) massive DNA damage, (2) dysfunction of the ubiquitinproteasomal system, (3) disruption of the axonal transport machinery, (4) abnormalities of mitochondrial structure and function, (4) disturbance of intracellular ionic homeostasis 
(particularly $\mathrm{Ca} 2+$ and $\mathrm{Zn} 2+$ ), and (5) accumulation of reactive oxygen species (ROS) in the neuronal cells. Accumulating intracellular stress subsequently results in (1) loss of spines and synapses, (2) fragmentation of neuronal processes and extended neuritic degeneration leading to demyelination, (3) global neuronal cell death leading to activation of signal transduction cascade for programmed cell death, (4) anomalies of microvasculature, and (5) provoked neuroinflammatory response leading to destructive pathogenic changes (see several representative reviews) [1-4]. Accordingly, the main aim of neural protection in neurodegenerative disorders is to retard progression by blocking the mechanisms that lead to neuronal cell death as well as associated neuroinflammatory events. Considerable efforts have been made in recent decades to discover new potential therapeutic compounds that can help to prevent the onset or to slow down the progression of such diseases. Equal attempts are in progress to improve the therapeutic efficacy of known medications through chemical modification. Given the evident advantages of being stable in the ambient environment, being permeable to the blood-brain and/or blood-eye barriers, and being convenient for administration (Fig. 1), naturopathic compounds have increasingly become suitable therapeutic candidates for neural protection from the sensory system including retina to the central nervous system (brain). Table 1 summarizes a group of selected herbal extracts that have demonstrated significant neuroprotective efficacy both in vivo and in vitro. Taking tetramethylpyrazine (TMP) as an example, the neuroprotective efficacy and related issues are discussed here.

\section{Tetramethylpyrazine, an herbal extract showing multiple protective effects on cells and benefits on physiological function}

As listed in Table 1, TMP, also designated as ligustrazine, is an alkaloid extracted from the Chinese herbal medicine, Ligusticum wallichii Franchat (chuanxiong) [5]. For hundreds of years, chuanxiong has been used as a traditional Chinese medicine for heart, kidney, and brain diseases $[6,7]$. Experimental studies demonstrated that TMP treatments significantly improved cardiac and cerebral blood flow and elevated blood reperfusion as shown in the nail microcirculation $[8,9]$. In an ex vivo study, a semi-synthetic form of TMP monomer induced a dose-dependent relaxation of human pulmonary and bronchial arteries [10]. TMP also exhibited a calcium antagonist role in vascular tissues [11]; functioned as a ROS scavenger to deactivate cytotoxic ROS such as superoxide anion $\left(\mathrm{O}^{-}-\right)$, hydroxyl $\left(\mathrm{OH}^{-}\right)$, and lipid peroxyl (LOO-) free radicals [12, 13]; and inhibited inflammatory events in vivo possibly through modulating secretion of specific cytokines and nitric oxide-related pathways [14-16].

About two decades ago, a study briefly reported that TMP alleviated ischemic retinal degeneration in vivo [17]. Recently, a different group of researchers demonstrated that systemic injection of TMP significantly protected retinal photoreceptors from loss induced by $N$-methyl- $N$-nitrosourea in rats [18]. Further, we demonstrated that TMP efficiently enhanced in vitro survival of cultured rat retinal cells and significantly attenuated cell damage in these cells exposed to hydrogen peroxide [19].
Fig. 1 The conventional route of most natural compounds from herbs to target organs. In the traditional Chinese medicine, the herbal therapeutic ingredients are extracted and prepared as herbal tea or soup with water through regular cooking and taken orally. The effective ingredients are absorbed by the gastrointestinal tract and successfully pass through the blood-brain and/or blood-eye barriers to reach the targets, brain and/or retinas (graphic clips were taken from the Internet free sources)
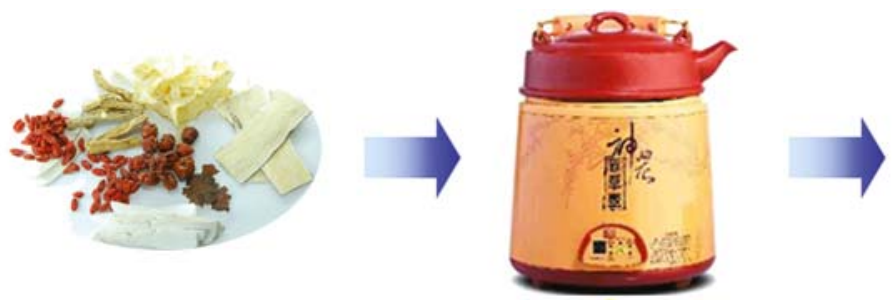

Herbs
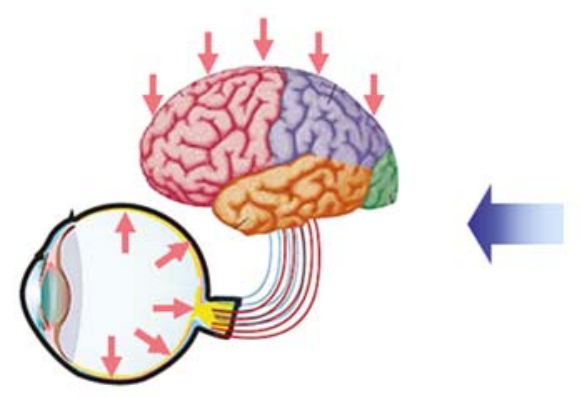

Extraction/cooking
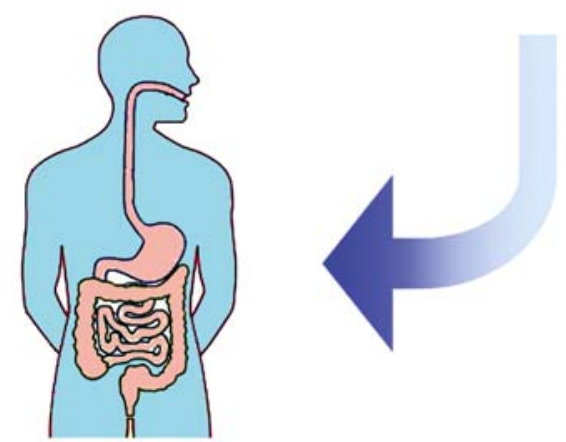

Blood-brain and blood-eye barriers-permeable Uptake by the gastrointestinal tract 
Table 1 List of selected naturopathic compounds that have demonstrated neuroprotective efficacy in both retina and brain

\begin{tabular}{llll}
\hline Name & Natural sources (selected) & Structural classification & Selected studies \\
\hline Baicalein & Radix scutellariae & Alkaloids & C [49, 50]; R [51, 52]; B [53, 54] \\
Chlorogenic acid & Eucommia or other plants & Polyphenolics & C [55]; R [56]; B [57, 58] \\
Curcumin & Curcuma longa & Alkaloids & C [59, 60]; R [59, 61]; B [60, 62, 63] \\
Emodin & Leguminosae seed & Alkaloids & C [64, 65]; R [66]; B [65, 67] \\
Fisetin & Rhus cotinus bark & Polyphenolics & C [68, 69]; R [70]; B [71] \\
Kaempferol & Euonymus alatus or Impatiens balsamina & Flavonoids & C [72, 73]; R [70, 74]; B [75] \\
Ligustrazine & Ligusticum wallichii roots & Alkaloids & C [19]; R [76]; B [23, 77] \\
Morin & The Moraceae family, e.g., mulberry & Flavonoids & C [78]; R [79]; B [80, 81] \\
Myricetin & Myrica rubra & Flavonoids & C [78]; R [74]; B [82] \\
Naringenin & Satureja obovata & Flavonoids & C [83]; R [84]; B [85] \\
Paeoniflorin & Paeony roots & Polyphenolics & C [86]; R [87]; B [88-90] \\
Puerarin & Pueraria lobata roots & Alkaloids & C [91, 92]; R [93, 94]; B [95, 96] \\
Pycnogenol & Pinus maritime bark & Flavonoids & C [97]; R [98, 99]; B [100] \\
Quercetin & Euonymus alatus & Flavonoids & C [101, 102]; R [84, 103]; B [104, 105]. \\
Resveratrol & Grapes & Flavonoids & C [106, 107]; R [108]; B [108-110] \\
Rutin & Buckwheat & Flavonoids & C [111]; R [84]; B [104] \\
Wogonin & Scutellaria baicalensis & Flavonoids & C [112, 113]; R [114]; B [115, 116] \\
\hline
\end{tabular}

$C$, in vitro studies conducted in cultured cells; $R$, in vivo studies showing retinal protection; $B$, in vivo studies demonstrating neuroprotective efficacy in the brain

In the CNS, TMP significantly suppressed oxidative stress and attenuated neuronal cell death in neuronal cultures following iron-mediated oxidative damage and glutamatemediated excitotoxicity [20-22]. Systemic administration of TMP protected neuronal cells against ischemic or traumatic brain or spinal cord injury and promoted functional recovery in rodents and rabbits [23, 24]. Interestingly, systemic administration of TMP also attenuated impairment of learning and memory performance in rodents following D-galactoseor ischemia-induced brain injury $[25,26]$. The potential therapeutic efficacy of TMP for AD is further supported by our recent observations about significant improvement of cognitive function as well as cerebral amyloid pathology in the demented Alzheimer's triple transgenic (3xTg-AD) mice (Tan et al., unpublished observations). These findings suggest that TMP has potent neuroprotective efficacy.

\section{TMP protects neuronal degeneration in rat brain against excitotoxicity—an experimental study}

Systemic administration of the excitotoxin, kainic acid (KA), a glutamate analog, causes prolonged seizures resulting in massive neuronal cell death in rat brain. KA-induced neuronal degeneration is one of the most common animal models for excitotoxic neuronal cell death, which is apparently involved in the pathogenesis of multiple neurodegenerative disorders [27-29]. One-month old male
Sprague-Dawley rats were housed and treated according to the National Institutes of Health guidelines for the care and use of laboratory animals and a protocol approved by the UCI Institutional Animal Care and Use Committee. One hour after the onset of seizures following subcutaneous (s.c.) injection of $\mathrm{KA}(10.5 \mathrm{mg} / \mathrm{kg})$, rats received TMP $(50 \mathrm{mg} / \mathrm{kg}$, s.c.) or an equal volume of vehicle. Untreated animals, which received neither KA not TMP, were used as blank controls. All the animals ( $N=6$ each group) were decapitated $24 \mathrm{~h}$ after TMP or vehicle injection under $\mathrm{CO}_{2}$ gas-induced deep anesthesia. The brain was rapidly harvested, frozen, and cryosectioned in the coronal plane at $10 \mu \mathrm{m}$. Adjacent sections from each brain were stained with hematoxylin-eosin (H \& E) and in situ cell death assay kit for terminal deoxytransferase-mediated dUTP nick end labeling (TUNEL; Roche, Indianapolis, IN, USA), respectively, as described in our previous work [30, 31].

Systemic administration of KA resulted in a welldescribed pattern of behavioral seizures including wet dog shake at the beginning stage and progressed to tonic-clonic activity [27]. Seizures typically occurred intermittently during the first $6-8 \mathrm{~h}$ and yielded about $10 \%$ or less mortality. As observed in this study, TMP treatments did not alter the pattern and the severity of the seizures. Brain sections from the animals that received "KA + vehicle" demonstrated robust neuronal degeneration in KA-vulnerable regions in brain as revealed by both $\mathrm{H}$ \& $\mathrm{E}$ staining and TUNEL labeling (Fig. 2a (f-j)) whereas the controls showed no eosinophilic 
Fig. 2 Systemic administration of TMP attenuates neuronal degeneration in rat brains following kainate-induced seizures. a Both hematoxylin$\operatorname{eosin}(\mathrm{H} \& \mathrm{E})$ and TUNEL staining demonstrate massive neuronal damage shown as pink in $\mathrm{H} \& \mathrm{E}$ staining $(f, g)$ and green in TUNEL $(h, i$, and $j)$ in both hippocampus $(f, g, h$, and $i)$ and piriform cortex $(j)$ regions. In contrast, the animals received TMP only exhibited a few sporadic eosinophilic $(l)$ and TUNEL-positive cells in the corresponding regions $(m, n$, and $o$ ). b Quantification of TUNEL-positive cells according to our previous methods reveals a significant decrease in the number of damaged neurons in the hippocampal regions with TMP treatment. Scale bar= $100 \mu \mathrm{m}$ in $b, d, e, g, i, j, l, n$, and $o$; and $400 \mu \mathrm{m}$ in $a, c, f, h, k$, and $m$ a
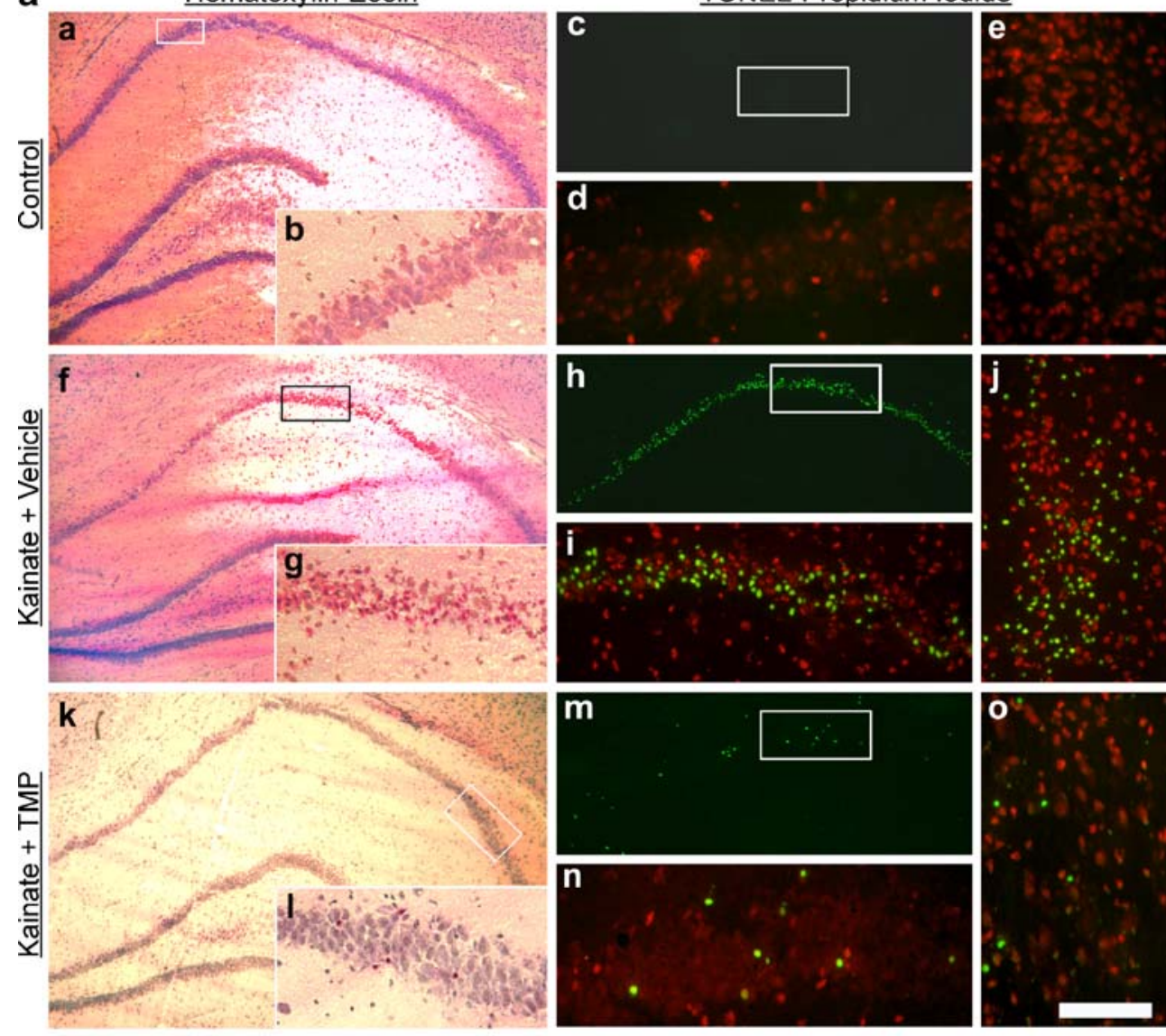

b

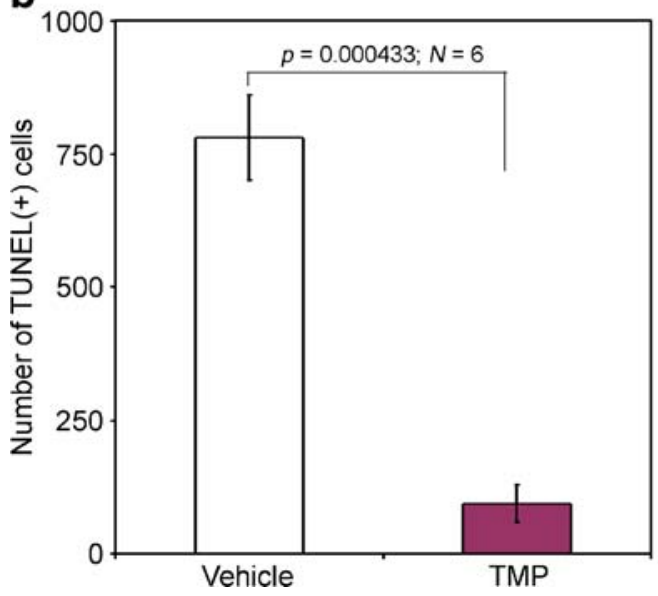

or TUNEL-positive damaged cells (Fig. 2a (a-e)). In contrast, given $50 \mathrm{mg} / \mathrm{kg}$ TMP following the onset of seizures, animals showed markedly fewer damaged cells in the corresponding regions in the brain (Fig. 2a $(\mathrm{k}-\mathrm{o})$ ). Quantification of TUNEL-positive cells conducted as described in our previous work $[32,33]$ revealed a statistically significant difference between "KA + vehicle" and "KA + TMP", suggesting remarkable neuroprotective efficacy of TMP in the CNS under excitotoxic attack.
In cultured neural cells, TMP treatments significantly reduced the generation of lipid peroxidation products, malondialdehyde, induced by hydrogen peroxide [19, 20]. These observations are also in agreement with increased levels of glutathione in 3xTg-AD mouse brains following TMP treatments (data not shown). In addition, the benefits of TMP treatments preserved high levels of MAP2 and rattin, two molecules that play important roles in cell growth and function [19, 34, 35]. Taken together, TMP may target 
multiple cell signal transduction pathways to contribute to the survival of neural cells and the normal function of the nervous system.

\section{How far is TMP from the next phase for clinical applications?}

As a naturopathic compound isolated from a Chinese herbal medicine, TMP has been the subject of many pharmacological and toxicological studies. The solubility of purified TMP in crystal form is relatively low in neutral aqueous solution $(\sim 10 \mu \mathrm{g} / \mathrm{ml})$ and dramatically increases in an acidic environment $(>40 \mathrm{mg} / \mathrm{ml}, \mathrm{pH}<4)$, in which TMP is stable and active [36]. Preclinical assessment of the distribution, metabolism, excretion, and toxicity (ADMET) of TMP has been performed in animals and in vitro for over 20 years [37-41]. Pharmacokinetic studies demonstrated that TMP was efficiently permeable to the blood-brain barrier in multiple animal models $[39,40]$. Toxicity assays revealed a very low level of toxicity in animals with an oral $\mathrm{LD}_{50}$ of about $1,910 \mathrm{mg} / \mathrm{kg}$ in rats and $1,436 \mathrm{mg} / \mathrm{kg}$ in mice [42, 43]. Of significance, practitioners of traditional Chinese medicine have continued to use TMP as a treatment for inflammatory or degenerative diseases, usually in combination with other medications $[6,8,44-46]$. In this regard, both TMP tablets and TMP-HCl injectable solution are prescription-available for the treatment of cardiovascular diseases in China [47, 48].

Given the favorable ADMET outcomes on TMP in animals, and the longstanding clinical use of TMP in China, the path is set for preclinical data to justify clinical trials of TMP in humans. This proof-of-concept proposal would provide sufficient preclinical evidence to justify studying TMP in patients with neurodegenerative disorders in a double-blind placebo-controlled manner. Our understanding of the molecular basis for TMP-mediated pharmacological actions remains limited. Similarly, there are a lack of well-designed preclinical studies of TMP efficacy for neurological disorders. Such studies are critical prior to studying TMP in humans.

\section{Summary}

In addition to TMP, there are groups of naturopathic compounds that have been purified from related herbal medicines and identified as efficient neuroprotective ingredients as mentioned. Resembling TMP, many of these compounds have demonstrated remarkable neuroprotective efficacy in experimental studies conducted in cell cultures and/or live animals. Some of them are also used in clinics as treatment for specific neurological disorders. Therefore, once further studies are warranted to decipher the molecular basis of related pharmacological efficacy, many of such naturopathic molecules would move to clinical assessments for neural protection in humans.

Acknowledgment This study is supported by a research grant from the Alzheimer's Drug Discovery Foundation.

Open Access This article is distributed under the terms of the Creative Commons Attribution Noncommercial License which permits any noncommercial use, distribution, and reproduction in any medium, provided the original author(s) and source are credited.

\section{References}

1. Bredesen DE, Rao RV, Mehlen P. Cell death in the nervous system. Nature. 2006;443:796-802.

2. Mattson MP. Neuronal life-and-death signaling, apoptosis, and neurodegenerative disorders. Antioxid Redox Signal. 2006;8:19972006.

3. Kazantsev AG. Cellular pathways leading to neuronal dysfunction and degeneration. Drug News Perspect. 2007;20:501-9.

4. Trushina E, McMurray CT. Oxidative stress and mitochondrial dysfunction in neurodegenerative diseases. Neuroscience. 2007; 145:1233-48.

5. Liu YH, Liu YF, Guo XX. Current studies on anti-endotoxic chemical components of traditional Chinese medicine in China. Acta Pharmacologica Sinica. 2001;22:1071-7.

6. Ho JW, Jie M. Pharmacological activity of cardiovascular agents from herbal medicine. Cardiovasc Hematol Agents Med Chem. 2007;5:273-7.

7. Xu H, Shi DZ, Guan CY. Clinical application and pharmacological actions of ligustrazine. Zhongguo Zhong Xi Yi Jie He Za Zhi. 2003;23:376-9.

8. Wang GJ. The change in the nailfold microcirculation in patients with acute cerebral thrombosis treated with ligustrazine. Zhonghua Shen Jing Jing Shen Ke Za Zhi. 1984;17:121-4.

9. Yan F, Luo R. Effects of ligustrazine on blood vessels and blood components. Zhong Yao Cai. 2002;25:143-5.

10. Liu SF, Cai YN, Evans TW, McCormack DG, Barer GR, Barnes PJ. Ligustrazine is a vasodilator of human pulmonary and bronchial arteries. Eur J Pharmacol. 1990;191:345-50.

11. Pang PK, Shan JJ, Chiu KW. Tetramethylpyrazine, a calcium antagonist. Planta Med. 1996;62:431-5.

12. Zhang ZH, Yu SZ, Wang ZT, Zhao BL, Hou JW, Yang FJ, et al. Scavenging effects of tetramethylpyrazine on active oxygen free radicals. Zhongguo Yao Li Xue Bao. 1994;15:229-31.

13. Zhang Z, Wei T, Hou J, Li G, Yu S, Xin W. Tetramethylpyrazine scavenges superoxide anion and decreases nitric oxide production in human polymorphonuclear leukocytes. Life Sci. 2003;72:2465-72.

14. Ozaki Y. Antiinflammatory effect of tetramethylpyrazine and ferulic acid. Chem Pharm Bull (Tokyo). 1992;40:954-6.

15. Chang Y, Hsiao G, Chen SH, Chen YC, Lin JH, Lin KH, et al. Tetramethylpyrazine suppresses HIF-1alpha, TNF-alpha, and activated caspase-3 expression in middle cerebral artery occlusion-induced brain ischemia in rats. Acta Pharmacologica Sinica. 2007;28:327-33.

16. Liao MH, Wu CC, Yen MH. Beneficial effects of tetramethylpyrazine, an active constituent of Chinese herbs, on rats with endotoxemia. Proc Natl Sci Counc Repub China B. 1998;22:46-54.

17. Chiou GC, Yan HY, Lei XL, Li BH, Shen ZF. Ocular and cardiovascular pharmacology of tetramethylpyrazine isolated from Ligusticum wallichii Franch. Zhongguo Yao Li Xue Bao. 1991;12:99-104. 
18. Yang JN, Chen JM, Luo L, Lin SC, Li D, Hu SX. Tetramethylpyrazine protected photoreceptor cells of rats by modulating nuclear translocation of NF-kappaB. Acta Pharmacologica Sinica. 2005;26:887-92.

19. Yang Z, Zhang Q, Ge J, Tan Z. Protective effects of tetramethylpyrazine on rat retinal cell cultures. Neurochem Int. 2008;52:1176-87.

20. Zhang Z, Wei T, Hou J, Li G, Yu S, Xin W. Iron-induced oxidative damage and apoptosis in cerebellar granule cells: attenuation by tetramethylpyrazine and ferulic acid. Eur J Pharmacol. 2003;467:41-7.

21. Shih YH, Wu SL, Chiou WF, Ku HH, Ko TL, Fu YS. Protective effects of tetramethylpyrazine on kainate-induced excitotoxicity in hippocampal culture. NeuroReport. 2002;13:515-9.

22. Liao SL, Kao TK, Chen WY, Lin YS, Chen SY, Raung SL, et al. Tetramethylpyrazine reduces ischemic brain injury in rats. Neurosci Lett. 2004;372:40-5.

23. Kao TK, Ou YC, Kuo JS, Chen WY, Liao SL, Wu CW, et al. Neuroprotection by tetramethylpyrazine against ischemic brain injury in rats. Neurochem Int. 2006;48:166-76.

24. Fan LH, Wang KZ, Cheng B, Wang CS, Dang XQ. Anti-apoptotic and neuroprotective effects of Tetramethylpyrazine following spinal cord ischemia in rabbits. BMC Neurosci. 2006;7:48.

25. Zhang C, Wang SZ, Zuo PP, Cui X, Cai J. Protective effect of tetramethylpyrazine on learning and memory function in Dgalactose-lesioned mice. Chin Med Sci J. 2004;19:180-4.

26. Ni JW, Matsumoto K, Watanabe H. Tetramethylpyrazine improves spatial cognitive impairment induced by permanent occlusion of bilateral common carotid arteries or scopolamine in rats. Jpn J Pharmacol. 1995;67:137-41.

27. Sperk G. Kainic acid seizures in the rat. Prog Neurobiol. 1994;42:1-32.

28. Salinska E, Danysz W, Lazarewicz JW. The role of excitotoxicity in neurodegeneration. Folia Neuropathol. 2005;43:322-39.

29. Casson RJ. Possible role of excitotoxicity in the pathogenesis of glaucoma. Clin Experiment Ophthalmol. 2006;34:54-63.

30. Tan Z, Tu W, Schreiber SS. Downregulation of free ubiquitin: a novel mechanism of p53 stabilization and neuronal cell death. Brain Res Mol Brain Res. 2001;91:179-88.

31. Tan Z, Levid J, Schreiber SS. Increased expression of Fas (CD95/APO-1) in adult rat brain after kainate-induced seizures. NeuroReport. 2001;12:1979-82.

32. Quach N, Chan T, Lu TA, Schreiber SS, Tan Z. Induction of DNA repair proteins, Ref-1 and XRCC1, in adult rat brain following kainic acid-induced seizures. Brain Res. 2005;1042:236-40.

33. Tan Z, Sankar R, Shin D, Sun N, Liu H, Wasterlain CG, et al. Differential induction of p53 in immature and adult rat brain following lithium-pilocarpine status epilepticus. Brain Res. 2002;928:187-93.

34. Dehmelt L, Halpain S. Actin and microtubules in neurite initiation: are MAPs the missing link? J Neurobiol. 2004;58: $18-33$.

35. Hashimoto Y, Niikura T, Tajima H, Yasukawa T, Sudo H, Ito Y, et al. A rescue factor abolishing neuronal cell death by a wide spectrum of familial Alzheimer's disease genes and Abeta. Proc Natl Acad Sci U S A. 2001;98:6336-41.

36. Qi X, Ackermann C, Sun D, Sheng M, Hou H. Physicochemical characterization and percutaneous delivery of 2, 3, 5, 6tetramethylpyrazine. Int J Pharm. 2003;253:177-83.

37. Ren P, Huang X, Jiang YP. Effect of sijunzi decoction on motilin and pharmacokinetic characteristics of tetramethylpyrazine in rat model of spleen deficiency syndrome. Zhongguo Zhong Xi Yi Jie He Za Zhi. 1997;17:45-7.

38. Lou YQ, Zhang H, Cao X, Chen ML. The pharmacokinetics and disposition of tetramethylpyrazine phosphate in dogs and rats. Yao Xue Xue Bao. 1986;21:481-7.
39. Tsai TH, Liang C. Pharmacokinetics of tetramethylpyrazine in rat blood and brain using microdialysis. Int J Pharm. 2001;216: 61-6.

40. Huang X, Ren $\mathrm{P}$, Wen AD, Wang LL, Zhang L, Gao F. Pharmacokinetics of traditional Chinese syndrome and recipe: a hypothesis and its verification (I). World $\mathrm{J}$ Gastroenterol. 2000;6:384-91.

41. Qi X, Ackermann C, Sun D, Liu R, Sheng M, Hou H. The prediction of plasma and brain levels of 2, 3, 5, 6-tetramethylpyrazine following transdermal application. AAPS PharmSci. 2002;4:E46.

42. Occelli E, Mariani L, Fontanella L, Corsico N. Substances with central nervous system activity. Derivatives of octahydro-1,4dihydroxypyrrolo(1,2-a)pyrazine-6-carboxylic acids. Farmaco [Sci]. 1984;39:718-38.

43. Adams TB, Doull J, Feron VJ, Goodman JI, Marnett LJ, Munro IC, et al. The FEMA GRAS assessment of pyrazine derivatives used as flavor ingredients. Flavor and Extract Manufacturers Association. Food Chem Toxicol. 2002;40:429-51.

44. Huang KJ, Williams WM. The pharmacology of Chinese herbs. Boca Raton: CRC; 1993.

45. Tang X. Effect of ligustrazine on proliferative glomerulonephritis. Zhong Yao Cai. 2003;26:611-2.

46. Gao BT. The effects of ligustrazine, aspirin and beta-histine on platelet aggregation in patients with acute ischemic stroke. Zhonghua Shen Jing Jing Shen Ke Za Zhi. 1989;22:148-51. 191.

47. Wang XF, Zhao MQ. Ligustrazine and Salvia miltiorrhiza injection solution in complementary therapy of pregnancyinduced hypertension: clinical analysis of 60 cases. Di Yi Jun Yi Da Xue Xue Bao. 2003;23:969-71.

48. Peng W, Duan SF. Effects of ligustrazine controlled release capsule in chronic pulmonary heart disease. J Tongji Med Univ. 1991;11:101-5.

49. Hanneken A, Lin FF, Johnson J, Maher P. Flavonoids protect human retinal pigment epithelial cells from oxidative-stressinduced death. Invest Ophthalmol Vis Sci. 2006;47:3164-77.

50. Lee HJ, Noh YH, Lee DY, Kim YS, Kim KY, Chung YH, et al. Baicalein attenuates 6-hydroxydopamine-induced neurotoxicity in SH-SY5Y cells. Eur J Cell Biol. 2005;84:897-905.

51. Yang L, Sun HL, Wu LM, Guo XJ, Dou H, Tso MO, et al. Baicalein reduces inflammatory process in a rodent model of diabetic retinopathy. Invest Ophthalmol Vis Sci. 2009;50:2319-27.

52. Wang SY, Wang HH, Chi CW, Chen CF, Liao JF. Effects of baicalein on beta-amyloid peptide-(25-35)-induced amnesia in mice. Eur J Pharmacol. 2004;506:55-61.

53. Sexton A, McDonald M, Cayla C, Thiemermann C, Ahluwalia A. 12-Lipoxygenase-derived eicosanoids protect against myocardial ischemia/reperfusion injury via activation of neuronal TRPV1. FASEB J. 2007;21:2695-703.

54. Wu PH, Shen YC, Wang YH, Chi CW, Yen JC. Baicalein attenuates methamphetamine-induced loss of dopamine transporter in mouse striatum. Toxicology. 2006;226:238-45.

55. Silva BA, Dias AC, Ferreres F, Malva JO, Oliveira CR. Neuroprotective effect of $H$. perforatum extracts on betaamyloid-induced neurotoxicity. Neurotox Res. 2004;6:119-30.

56. Nakajima Y, Shimazawa M, Mishima S, Hara H. Water extract of propolis and its main constituents, caffeoylquinic acid derivatives, exert neuroprotective effects via antioxidant actions. Life Sci. 2007;80:370-7.

57. Bouayed J, Rammal H, Dicko A, Younos C, Soulimani R. Chlorogenic acid, a polyphenol from Prunus domestica (Mirabelle), with coupled anxiolytic and antioxidant effects. J Neurol Sci. 2007;262:77-84.

58. Ohnishi R, Ito H, Iguchi A, Shinomiya K, Kamei C, Hatano T, et al. Effects of chlorogenic acid and its metabolites on spontaneous locomotor activity in mice. Biosci Biotechnol Biochem. 2006;70:2560-3. 
59. Mandal MN, Patlolla JM, Zheng L, Agbaga MP, Tran JT, Wicker L, et al. Curcumin protects retinal cells from light- and oxidant stress-induced cell death. Free Radic Biol Med. 2009; 46:672-9.

60. Jagatha B, Mythri RB, Vali S, Bharath MM. Curcumin treatment alleviates the effects of glutathione depletion in vitro and in vivo: therapeutic implications for Parkinson's disease explained via in silico studies. Free Radic Biol Med. 2008;44:907-17.

61. Matteucci A, Frank C, Domenici MR, Balduzzi M, Paradisi S, Carnovale-Scalzo G, et al. Curcumin treatment protects rat retinal neurons against excitotoxicity: effect on $N$-methyl-Daspartate-induced intracellular $\mathrm{Ca}(2+)$ increase. Exp Brain Res. 2005; 167:641-8.

62. Shukla PK, Khanna VK, Ali MM, Khan MY, Srimal RC. Antiischemic effect of curcumin in rat brain. Neurochem Res. 2008;33:1036-43.

63. Rathore P, Dohare P, Varma S, Ray A, Sharma U, Jaganathanan NR, et al. Curcuma oil: reduces early accumulation of oxidative product and is anti-apoptogenic in transient focal ischemia in rat brain. Neurochem Res. 2008;33:1672-82.

64. Lin HJ, Lai CC, Lee Chao PD, Fan SS, Tsai Y, Huang SY, et al. Aloe-emodin metabolites protected $N$-methyl-D-aspartate-treated retinal ganglion cells by $\mathrm{Cu}-\mathrm{Zn}$ superoxide dismutase. J Ocul Pharmacol Ther. 2007;23:152-71.

65. Wang C, Zhang D, Ma H, Liu J. Neuroprotective effects of emodin-8-O-beta-D-glucoside in vivo and in vitro. Eur $\mathrm{J}$ Pharmacol. 2007;577:58-63.

66. Kramerov AA, Saghizadeh M, Pan H, Kabosova A, Montenarh $\mathrm{M}$, Ahmed $\mathrm{K}$, et al. Expression of protein kinase CK2 in astroglial cells of normal and neovascularized retina. Am J Pathol. 2006;168:1722-36.

67. Gu JW, Hasuo H, Takeya M, Akasu T. Effects of emodin on synaptic transmission in rat hippocampal CA1 pyramidal neurons in vitro. Neuropharmacology. 2005;49:103-11.

68. Soliman KF, Mazzio EA. In vitro attenuation of nitric oxide production in $\mathrm{C} 6$ astrocyte cell culture by various dietary compounds. Proc Soc Exp Biol Med. 1998;218:390-7.

69. Zheng LT, Ock J, Kwon BM, Suk K. Suppressive effects of flavonoid fisetin on lipopolysaccharide-induced microglial activation and neurotoxicity. Int Immunopharmacol. 2008;8: 484-94.

70. Park YH, Xu XR, Chiou GC. Structural requirements of flavonoids for increment of ocular blood flow in the rabbit and retinal function recovery in rat eyes. J Ocul Pharmacol Ther. 2004;20:189-200.

71. Dajas F, Rivera F, Blasina F, Arredondo F, Echeverry C, Lafon $\mathrm{L}$, et al. Cell culture protection and in vivo neuroprotective capacity of flavonoids. Neurotox Res. 2003;5:425-32.

72. Wang CN, Chi CW, Lin YL, Chen CF, Shiao YJ. The neuroprotective effects of phytoestrogens on amyloid beta protein-induced toxicity are mediated by abrogating the activation of caspase cascade in rat cortical neurons. J Biol Chem. 2001;276:5287-95.

73. Samhan-Arias AK, Martin-Romero FJ, Gutierrez-Merino C. Kaempferol blocks oxidative stress in cerebellar granule cells and reveals a key role for reactive oxygen species production at the plasma membrane in the commitment to apoptosis. Free Radic Biol Med. 2004;37:48-61.

74. Laabich A, Manmoto CC, Kuksa V, Leung DW, Vissvesvaran GP, Karliga I, et al. Protective effects of myricetin and related flavonols against $\mathrm{A} 2 \mathrm{E}$ and light mediated-cell death in bovine retinal primary cell culture. Exp Eye Res. 2007;85:154-65.

75. Lopez-Sanchez C, Martin-Romero FJ, Sun F, Luis L, Samhan-Arias AK, Garcia-Martinez V, et al. Blood micromolar concentrations of kaempferol afford protection against ischemia/reperfusion-induced damage in rat brain. Brain Res. 2007;1182:123-37.
76. Chao HM, Lin DE, Chang Y, Hsu WM, Lee SM, Lee FL, et al. Ferulic acid, but not tetramethylpyrazine, significantly attenuates retinal ischemia/reperfusion-induced alterations by acting as a hydroxyl radical scavenger. J Ocul Pharmacol Ther. 2008;24: 461-72.

77. Chen KJ, Chen K. Ischemic stroke treated with Ligusticum chuanxiong. Chin Med J (Engl). 1992;105:870-3.

78. Ono K, Yoshiike Y, Takashima A, Hasegawa K, Naiki H, Yamada M. Potent anti-amyloidogenic and fibril-destabilizing effects of polyphenols in vitro: implications for the prevention and therapeutics of Alzheimer's disease. J Neurochem. 2003;87:172-81.

79. Amaratunga A, Fine RE. Generation of amyloidogenic Cterminal fragments during rapid axonal transport in vivo of beta-amyloid precursor protein in the optic nerve. J Biol Chem. 1995;270:17268-72.

80. Gottlieb M, Leal-Campanario R, Campos-Esparza MR, SanchezGomez MV, Alberdi E, Arranz A, et al. Neuroprotection by two polyphenols following excitotoxicity and experimental ischemia. Neurobiol Dis. 2006;23:374-86.

81. Ibarretxe G, Sanchez-Gomez MV, Campos-Esparza MR, Alberdi E, Matute C. Differential oxidative stress in oligodendrocytes and neurons after excitotoxic insults and protection by natural polyphenols. Glia. 2006;53:201-11.

82. Oyama Y, Fuchs PA, Katayama N, Noda K. Myricetin and quercetin, the flavonoid constituents of Ginkgo biloba extract, greatly reduce oxidative metabolism in both resting and $\mathrm{Ca}(2+)$ loaded brain neurons. Brain Res. 1994;635:125-9.

83. Zbarsky V, Datla KP, Parkar S, Rai DK, Aruoma OI, Dexter DT. Neuroprotective properties of the natural phenolic antioxidants curcumin and naringenin but not quercetin and fisetin in a 6-OHDA model of Parkinson's disease. Free Radic Res. 2005;39: 1119-25.

84. Chiou GC, Xu XR. Effects of some natural flavonoids on retinal function recovery after ischemic insult in the rat. $\mathrm{J}$ Ocul Pharmacol Ther. 2004;20:107-13.

85. Baluchnejadmojarad T, Roghani M. Effect of naringenin on intracerebroventricular streptozotocin-induced cognitive deficits in rat: a behavioral analysis. Pharmacology. 2006;78:193-7.

86. Tsai TY, Wu SN, Liu YC, Wu AZ, Tsai YC. Inhibitory action of L-type Ca2+ current by paeoniflorin, a major constituent of peony root, in NG108-15 neuronal cells. Eur J Pharmacol. 2005; 523:16-24.

87. Li J, Xiong X, Liu Y. Protective effect of paeoniflorin against optic nerve crush. Journal of Huazhong University of Science and Technology. 2007;27:650-2.

88. Liu J, Jin DZ, Xiao L, Zhu XZ. Paeoniflorin attenuates chronic cerebral hypoperfusion-induced learning dysfunction and brain damage in rats. Brain Res. 2006;1089:162-70.

89. Liu HQ, Zhang WY, Luo XT, Ye Y, Zhu XZ. Paeoniflorin attenuates neuroinflammation and dopaminergic neurodegeneration in the MPTP model of Parkinson's disease by activation of adenosine A1 receptor. Br J Pharmacol. 2006;148:314-25.

90. Tsuda T, Sugaya A, Ohguchi H, Kishida N, Sugaya E. Protective effects of peony root extract and its components on neuron damage in the hippocampus induced by the cobalt focus epilepsy model. Exp Neurol. 1997;146:518-25.

91. Dong LP, Wang TY. Effects of puerarin against glutamate excitotoxicity on cultured mouse cerebral cortical neurons. Zhongguo Yao Li Xue Bao. 1998;19:339-42.

92. Lin F, Xin Y, Wang J, Ma L, Liu J, Liu C, et al. Puerarin facilitates $\mathrm{Ca}(2+)$-induced $\mathrm{Ca}(2+)$ release triggered by $\mathrm{KCl}$ depolarization in primary cultured rat hippocampal neurons. Eur J Pharmacol. 2007;570:43-9.

93. Teng Y, Cui H, Yang M, Song H, Zhang Q, Su Y, et al. Protective effect of puerarin on diabetic retinopathy in rats. Mol Biol Rep. 2008;36:1129-33. 
94. Xuan B, Zhou YH, Yang RL, Li N, Min ZD, Chiou GC. Improvement of ocular blood flow and retinal functions with puerarin analogs. J Ocul Pharmacol Ther. 1999;15:207-16.

95. Xu XH, Zhao TQ. Effects of puerarin on D-galactose-induced memory deficits in mice. Acta Pharmacologica Sinica. 2002;23:587-90.

96. Xu X, Zhang S, Zhang L, Yan W, Zheng X. The Neuroprotection of puerarin against cerebral ischemia is associated with the prevention of apoptosis in rats. Planta Med. 2005;71:585-91.

97. Kobayashi MS, Han D, Packer L. Antioxidants and herbal extracts protect HT-4 neuronal cells against glutamate-induced cytotoxicity. Free Radic Res. 2000;32:115-24.

98. Schonlau F, Rohdewald P. Pycnogenol for diabetic retinopathy. A review. Int Ophthalmol. 2001;24:161-71.

99. Spadea L, Balestrazzi E. Treatment of vascular retinopathies with Pycnogenol. Phytother Res. 2001;15:219-23.

100. Veurink G, Liu D, Taddei K, Perry G, Smith MA, Robertson TA, et al. Reduction of inclusion body pathology in ApoE-deficient mice fed a combination of antioxidants. Free Radic Biol Med. 2003;34:1070-7.

101. Kook D, Wolf AH, Yu AL, Neubauer AS, Priglinger SG, Kampik A, et al. The protective effect of quercetin against oxidative stress in the human RPE in vitro. Invest Ophthalmol Vis Sci. 2008;49:1712-20.

102. Areias FM, Rego AC, Oliveira CR, Seabra RM. Antioxidant effect of flavonoids after ascorbate/ $\mathrm{Fe}(2+)$-induced oxidative stress in cultured retinal cells. Biochem Pharmacol. 2001;62:111-8.

103. Ishii Y, Kwong JM, Caprioli J. Retinal ganglion cell protection with geranylgeranylacetone, a heat shock protein inducer, in a rat glaucoma model. Invest Ophthalmol Vis Sci. 2003;44:1982-92.

104. Pu F, Mishima K, Irie K, Motohashi K, Tanaka Y, Orito K, et al. Neuroprotective effects of quercetin and rutin on spatial memory impairment in an 8-arm radial maze task and neuronal death induced by repeated cerebral ischemia in rats. J Pharmacol Sci. 2007;104:329-34.

105. Cho JY, Kim IS, Jang YH, Kim AR, Lee SR. Protective effect of quercetin, a natural flavonoid against neuronal damage after transient global cerebral ischemia. Neurosci Lett. 2006;404: 330-5.
106. Bureau G, Longpre F, Martinoli MG. Resveratrol and quercetin, two natural polyphenols, reduce apoptotic neuronal cell death induced by neuroinflammation. J Neurosci Res. 2008;86:403-10.

107. Parker JA, Arango M, Abderrahmane S, Lambert E, Tourette C, Catoire $\mathrm{H}$, et al. Resveratrol rescues mutant polyglutamine cytotoxicity in nematode and mammalian neurons. Nat Genet. 2005;37:349-50.

108. Mozaffarieh M, Grieshaber MC, Orgul S, Flammer J. The potential value of natural antioxidative treatment in glaucoma. Surv Ophthalmol. 2008;53:479-505.

109. Marambaud P, Zhao H, Davies P. Resveratrol promotes clearance of Alzheimer's disease amyloid-beta peptides. J Biol Chem. 2005;280:37377-82.

110. Ates O, Cayli SR, Yucel N, Altinoz E, Kocak A, Durak MA, et al. Central nervous system protection by resveratrol in streptozotocininduced diabetic rats. J Clin Neurosci. 2007;14:256-60.

111. Almaas R, Saugstad OD, Pleasure D, Rootwelt T. Neuronal formation of free radicals plays a minor role in hypoxic cell death in human NT2-N neurons. Pediatr Res. 2002;51:136-43.

112. Nakamura N, Hayasaka S, Zhang XY, Nagaki Y, Matsumoto M, Hayasaka $Y$, et al. Effects of baicalin, baicalein, and wogonin on interleukin-6 and interleukin-8 expression, and nuclear factorkappab binding activities induced by interleukin-1beta in human retinal pigment epithelial cell line. Exp Eye Res. 2003;77:195202.

113. Cho J, Lee HK. Wogonin inhibits excitotoxic and oxidative neuronal damage in primary cultured rat cortical cells. Eur J Pharmacol. 2004;485:105-10.

114. Nagaki Y, Hayasaka S, Kadoi C, Nakamura N, Hayasaka Y. Effects of scutellariae radix extract and its components (baicalein, baicalin, and wogonin) on the experimental elevation of aqueous flare in pigmented rabbits. Jpn J Ophthalmol. 2001;45:216-20.

115. Shieh DE, Liu LT, Lin CC. Antioxidant and free radical scavenging effects of baicalein, baicalin and wogonin. Anticancer Res. 2000;20:2861-5.

116. Cho J, Lee HK. Wogonin inhibits ischemic brain injury in a rat model of permanent middle cerebral artery occlusion. Biol Pharm Bull. 2004;27:1561-4. 